\title{
An Appraisal of Education Policy Implementation and Challenge of Leadership in Nigerian Universities
}

\author{
Dr. C.N. Ozurumba, Dr. V.O. Ebuara \\ Department Of Educational Foundations Niger Delta University, Wilberforce Island, PMB 071, Yenagoa, \\ Bayelsa State, Nigeria \\ Department Of Educational Administration And Planning University Of Calabar
}

\begin{abstract}
This paper sought to appraise education policy implementation and challenges of leadership. The problems associated with the implementation of educational policy are highlighted in this paper. The paper observed that the success of any educational policy is dependent on leadership delivery of services. To achieve the purpose of this study, three hypotheses were formulated to guide the study. Survey research design was adopted using stratified random sampling technique for the study. A sample of 500 academic staff was used out of a population of 10,000 academic staff. The instrument used for data collection was a self-designed questionnaire. The reliability of the instrument was determined through test-retest method which gave a reliability coefficient value of 0.78 . Independent $t$-test statistical tool was used for data analysis. The result revealed that our leaders who implement education policies need to be astute and articulate in their implementation. The paper recommend among others that those who implement education policy should be practically focused and avoid theoretical considerations.
\end{abstract}

\section{Introduction}

Education policy is a projected programme of educational activities, which specifics the goals, values and practices of the educational system. It is a statement which guides and direct all actions directed at achieving goal leading to national development through the educational sector. (NPE, 2004). Education policy provides the basis to regulate and control the conduct of the national educational system. These policies are thus formulated to meet the desires and aspiration of a people, community and the entire nation (Edem, 2006).

In Nigeria, educational policy which constitutes the centre piece of any meaningful analysis and useful assessment of recent development in Nigeria educational system was formulated based on the country's national philosophy that aimed at creating.

A free and democratic society

A just and equalitarian society

A United, strong and self-reliant nation,

A great and dynamic economy

A land of bright and full opportunities for all citizens.

It is important to note that the nation's policy on education is government way of realizing that part of the national goals which can be achieved using education as a tool. Therefore in line with above national goals, Nigeria's philosophy of education have been articulated to guide the development, integration and provision of equal access to educational opportunities for all citizens of the country.

Every government leader is charged with the responsibility of formulating policy which must be used as a basis for guiding the administrative machinery of the organization. In formulating the education policy the challenge before universities leaders of today, is that, these leaders must squarely face decisions about means, aims and values. This has become pertinent in the sense that all policies formulated should be seen as essential ingredients that serves as the bedrock on which educational programme of activities are built upon for the development, progress and total benefits of the system and society. Since educational policies deals with both general and specific procedures of what is to be done, and how the deferent operations of the education system will be carried out, educational planners or policy formulators must be conscious about policies being formulated and ensure that there is a stable political and conducive environment to enable the educational sector to have efficient, effective and qualitative delivery of services for improvement of the citizenry and the society (Okeke, 1997). Moreso, Leaders of Universities education system should be conversant with the fact that once education policy is made it must be successfully implemented or put into action so as to enhance rapid transformation of the education sector.

Such policy when implemented should also ensure that facilities and human resources are adequately provided for, in order to achieve the policy goals and objectives. At the implementation stage the responsibility of universities leaders or Government is enormous. According to Agabi (2002) policies are made and implemented normally to reflect the values, wishes, programmes and ideology of the government in power and 
it is at this level that decisions are made to initiate changes or shifts between types of education and programmes. Thus, environment where the policy operates and the societal needs may changes while implementation is on. At this juncture, it may be suggested that policy programmes could be frequently reviewed to meet up the challenges of the time. In most cases the function of leaders is to make sure that all decisions are within the confines of the educational policy and that no decision on implementation deviates from the overall policy document.

On this note, Nwosu (2010) emphasized that, obviously for the implementation stage to meet the needs of the society, carefulness, commitment, administrative willingness and efficacy or efficiency are required for the successful implementation of the stated and designed programme of activities. In Nigeria education system today, policy outcome is below expectations or poor due to lack of patriotic leadership as well as Government's consistent poor attitude towards the education sub-sector, manifesting in dishonest financial allocations to the sector and in the apathy towards teachers welfare during the process of translating policy into practice.

\section{Statement of the problem}

The Nigeria National Policy on Education was a significant attempt not only to plan but also to develop education to such a level that it would enhance the progress of the nation. This education policy is no doubt very wonderful in theory, a dependable document, brilliantly conceived and excellently documented but still unachievable up to date. Its provisions have a foresight and dynamism which can be a relevant launching pad to Nigerians yearning for national unity, stability and advancement of science and technological education. In practice however, only a few aspects of the policy are being realized by our leaders, the rest remain a mirage. This unfortunate situation could be blamed on lack of patriotic leadership, lack of determination on the part of policy implementors, religious intolerance or fundamentalism, ethnic chauvinism, that leads to placement of unsuitable personnel to man education sector, schools have registered more failure than success and wide spread examination irregularities has become the order of the day. It is against this backdrop that this study was embarked upon.

\section{Hypotheses}

The following hypotheses were formulated to guide the study.

1. There is no significant difference in the factors that influence education policy implementation between Professional and none professional administrators of Federal Universities.

2. There is no significant difference in the factors that influence education policy implementation between Professional and none professional experienced and non experienced administrators of Federal Universities.

3. There is no significant difference in the factors that influence education policy implementation between male and female administrators of Federal Universities.

\section{Methodology}

In this study, the survey design was adopted. The population comprises all staff of two Federal and two states universities in Nigeria estimated at about 10,000 staff. A stratified random sampling technique was used to select a total of 500 staff as respondents. Stratified technique was used so as to reflect all the variables under study, such as (type of university, sex, age, experience, and socio-economic background). 300 respondents were selected from two federal universities and 200 respondents were selected from two states universities. The instrument used to elicit responses was a self-designed questionnaires by the researchers titled: Appraisal of Educational Policy Implementation and the Challenges of Leadership (AEPICL) consisting two sections. Section 'A' was a biographical data of the staff, section, 'B' was based on a 25 items measuring Education Policy Implementation and Leadership Challenges. The items were responded to on a four-point scale of strongly agree (4point), Agree (3point) disagree (2point) and strongly disagree (1point).

The questionnaire was subjected to face content validation by three experts on measurement and evaluation in the Faculty of Education. Their comments and observations were utilized after restructuring some of the items in the instrument. The reliability of the instrument was determined through test-retest method, using 30 staff who were not part of the study sample. A reliability coefficient value of 0.78 was obtained. The value was high enough to guarantee its use for the study. Independent t-test statistical tool was used for data analysis.

\section{Hypothesis I}

\section{Results}

There is no significant difference in the factors that influence education policy implementation between professional and non professional administrators of Federal universities. 
Table I: Influence of education policy implementation between administrative leaders of universities.

\begin{tabular}{|c|c|c|c|c|c|c|c|c|}
\hline Variables & & $\mathbf{N}$ & $\mathbf{X}$ & SD & Df & t-cal & t-crit & Result \\
\hline $\begin{array}{l}\text { Professional } \\
\text { Administrative Leaders } \\
\text { Of Federal universities }\end{array}$ & & 150 & 50.6 & 16.97 & & & & \\
\hline $\begin{array}{l}\text { Non Processional } \\
\text { Administrative leaders } \\
\text { of universities }\end{array}$ & 150 & 46.0 & 11.30 & & 298 & 2.7 & 1.96 & Sign. \\
\hline
\end{tabular}

Significant at 0.05 alpha, $d f=298$, critical $t=1.96$

Table one showed that professional administrative leaders of federal universities have a higher mean score of (50.6) than the non-professional administrative leaders of federal universities (46.0) in the implementation of education policy when subjected to statistical test. The calculated value of $t=2.7$ is greater than the critical t-value of 1.96 needed for significance at 0.05 with 298 degrees of freedom, therefore the null hypothesis is rejected, in meaning that professional administrators of Federal Universities significantly influence the educational policy implementation process.

\section{Hypothesis 2}

There is no significant difference in the factors that influence education policy implementation between experienced and inexperienced administrators of Federal universities.

Table 2: Influence of education policy implementation between experienced and inexperienced administrator of universities.

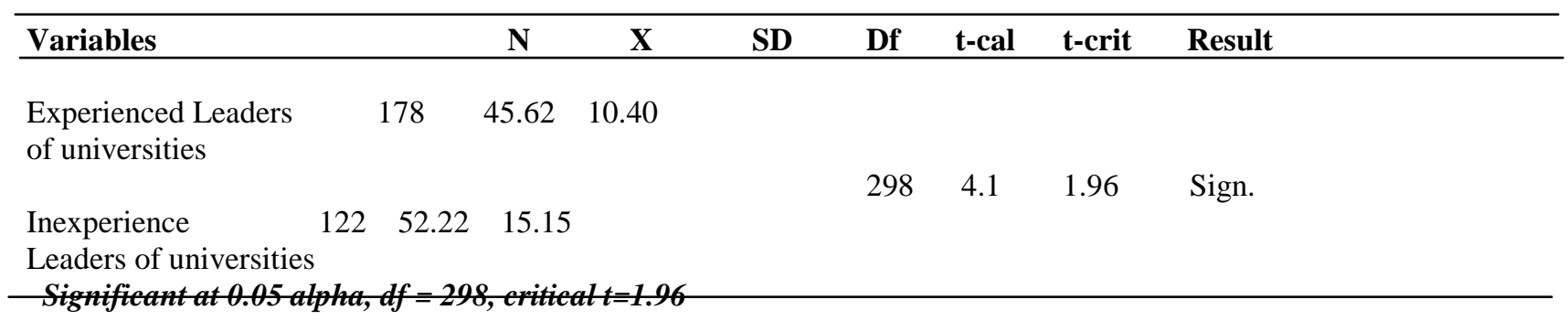

Analysis on table 2 showed that the calculated t-value of 4.1 is greater than the critical $t$-value of 1.96 required for significance at 0.05 level with 298 degrees of freedom, hence the null hypothesis is rejected and the alternative is accepted. This means implementation of education policy is influence by the experienced or inexperienced level of Administrative leaders of universities.

\section{Hypothesis 3}

There is no significant difference in the factors that influence education policy implementation between Male and Female administrative leaders of Federal universities.

Table 3: Influence of education policy implementation between male and female administrative leaders of universities.

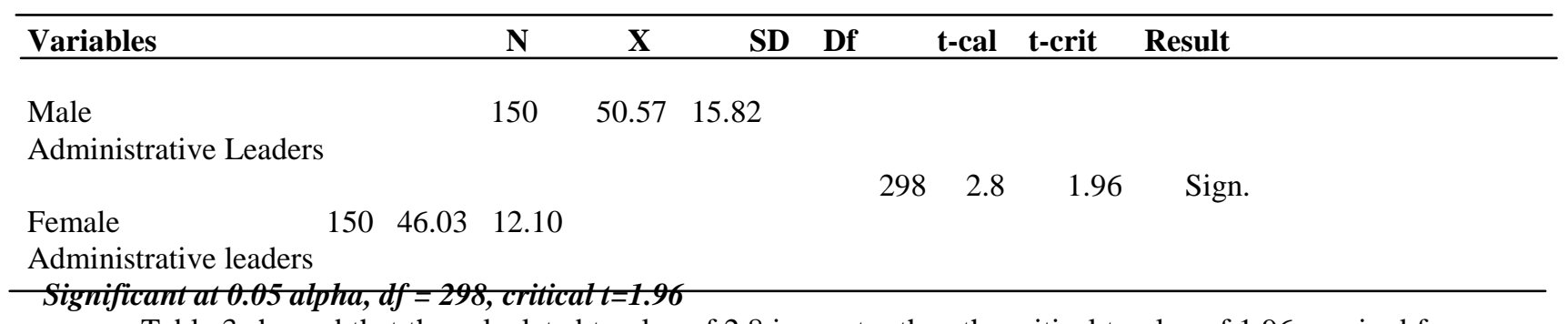

Table 3 showed that the calculated t-value of 2.8 is greater than the critical t-value of 1.96 required for significant of 0.05 level with 298 degree of freedom, hence the null hypothesis is rejected. 
This means that there is a significant influence of male and female leaders on education policy implementation in universities.

\section{Discussion}

The result of hypothesis one was rejected showing that education policy implementation is significantly influenced by the training level of administrators of Federal Universities. Moreso, the result on the table showed that professional administrative leaders of Federal universities have a higher mean score than the none professional administrators.

This is in line with the view of Unimna (2002) who affirmed that although, the provisions of the education policy had a foresight and dynamism, in practice, however, only few aspects of the policy have so far been realized while the rest remained a mirage. This lag in implementation level among universities administrators, unimna stressed is due to lack of determination on the part of policy implementators as well as lack of patriotic leadership, training and professionalism. Hence, the goals of education policy has remained unachievable as performance revealed that much is left to be done in the educational system.

When the education policies are implemented by professionals in the education system, they render different kinds of services to meet the variety of needs of the society. Professional administrators of educational system are those that possessed competency in their chosen field that can effectively under services that are rewarding and fulfilling in implementing education policy. The services the professionals render unlike nonprofessional administrators are usually in the forms of manpower production for the different sectors of the society (Joshua, 2002) Hardly do administrators who are non-professional leaders in education system do well. They are very often observed by the society as quacks. The feeling of the public concerning them is that these personalities lack the expected training, skills and competence to perform/deliver.

Furthermore, hypothesis two was rejected meaning that experience had significant influence on implementation of education policy. University administrative leaders who are experienced and more knowledgeable execute policies with better results than inexperienced ones not trained and not competent. The success of any education system depends to a great extent on the qualified, experienced and committed leadership. According to Adepoju (2011) lack of experienced administrators to implement education policy has been observed as a recurring issue in Nigeria due to frequent changes in government and leadership whereby every government that assumed power always like to introduced its policies to suit the government in power and this eventually constitutes a problem to meaningful operation of the policies and system. This frequent charge in educational policies is as a result of the political instability in the country which does not favour meaningful planning and execution of suitable education policies and programme that would last for a long time.

The null hypothesis three was rejected meaning that there is a significant influence of sex on the implementation of education policy in Nigeria. The finding further revealed that male administrators of universities are more competent in the implementation of education policy. This finding might be due to the freedom of male administrators from domestic responsibilities and perform most difficult chores than their female counterpart. This is in consonance with Ethothi (2001) who asserted that female administrators of universities lacked the professional ethics, skills and patriotic leadership to accommodate and exhibit the knowledge of successfully implementing policy in education system. In conclusion, he affirmed that the task of education policy implementation is a colossal one that needs an astute, articulate and relentless effort that would be continuous towards realization of education goals. In otherwords, the policy need to be constantly reviewed to ensure its adequacy and continued relevance to national education needs and objectives.

\section{Conclusion}

Some vital implications for a successful education policy implementation evolved from the findings of this study. The analysis of results and discussion of findings have shown that the challenge before our leaders in execution of education policy is the one that needs an astute and articulate implementators. An evaluation of education policy implementation was to be a continuous process. In view of this there is need for stability of government policies and programmes to enhance attainment of education objectives. Education policy implementors should therefore devote more time money and resources to education sub-section.

\section{Recommendations}

1. Appropriate arrangement should be made to put competently trained and experienced universities administrators in office and also to adequately motivate them to perform creditably.

2. The policy should constantly be reviewed not for selfish personal interest but ensure its adequacy and continued relevance to national needs and objectives.

3. Government should consistently fund education sector through financial allocation to enable those who implement policy realized practically the education policy objectives.

4. In the implementation process, emphasis should be placed on qualitative manpower/material resources. 
5. The process of education policy implementation should be practically focused and avoid theoretical considerations.

6. Stakeholders of education system should avoid politicking issues in education to enable implementation of the policy attained the objectives for which it was formulated.

\section{References}

[1]. Adepoju, I. L. (2011). Educational Policies, Practices and Strategies for Achieving Reform in Education. Akure: Tamaza Publishing Company Limited.

[2]. Agabi, O. G. (2002). Finance and Economic of Public Education. Port Harcourt: Nigeria, International Centre for Educational Services.

[3]. Edem, F. S. (2006). Handbook of Educational Foundations, Jos: Challenge Press.

[4]. Ethothi, K. E. (2001). An Appraisal of Policy Formulation only Implementation on Teacher Education in Nigeria Journal of Educational Issues 1(3) 42-54.

[5]. Joshua, M. T. (2002). Professional Competence Evaluation Nigerian Educational Journal 1(2), 264-270.

[6]. Federal Republic of Nigeria (2004) National Policy on Education (Revised) Lagos: Federal Ministry of Education.

[7]. Nwosu, O. (2010). Philosophy of Nigerian Education: A Foundational Approach: Ugwashi-UKU: Mantin Industrial Press \& Publishing Company.

[8]. Unimna, A. G. (2002). Educational as an Instrument of Social Cohesion and a Change in Nigeria in Journal of Education 2, $230-242$.

[9]. Udo, N. N. (2002). An Appraisal of the Implementation of National Policy on Education in Cross River State: Implication for physic Teaches, in Journal of Education. 2(13-22). 